\title{
The role of yoghurt in the prevention and treatment of obesity and related diseases
}

\begin{abstract}
A total of 67 subjects with central type obesity ( 26 men and 41 women) were enrolled in the study aiming to determine the effect of yoghurt fermented by Bifidus essensis $(0.5 \%$ fat $)$ in the treatment of patients with obesity and related diseases. A decrease of BMI, fat mass, visceral fat, waist circumference, hip circumference and sagittal diameter has been observed and presented in the current article.
\end{abstract}

Keywords: anthropometric study, yoghurt, probiotics, metabolic syndrome
Volume 6 Issue 5 - 2018

\author{
Teodora Handjieva-Darlenska, ${ }^{1,2}$ Stella \\ Shekerdjiiska, ${ }^{2}$ Nikolay Georgiev ${ }^{2}$ \\ 'Medical University of Sofia, Bulgaria \\ ${ }^{2}$ Bulgarian Association for the Study of Obesity and Related \\ Diseases, Bulgaria
}

Correspondence: Svetoslav Handjiev, Bulgarian Association for the Study of Obesity and Related Diseases, Bulgaria, Email svhandjiev@gmail.com

Received: July 30, 2018 | Published: September 14, 2018

\section{Introduction}

Obesity is a chronic metabolic disease which leads to many comorbidities and high prevalence of mortality. The incidence of obesity and related diseases increases constantly. The role of the dairy products in the treatment and prevention of obesity has been discussed. The effect of yoghurt, respectively probiotics in the treatment and prevention of obesity has been discussed.

The aim of our study was to investigate the effect of yoghurt fermented by Bifidus essensis $(0.5 \%$ fat $)$ in the treatment of patients with obesity and related diseases.

\section{History}

Even since the end of $19^{\text {th }}$ century, the Russian scientist and pioneer immunologist Ilya Ilyich Mechnikov (or Elie Metchnikoff, as his name is often written), investigating the factors that could enhance or decrease health and longevity, advanced the idea of the harmful intestinal bacteria as the source of the inflammatory process; the thermal preparation of all fruits and vegetables and the regular consumption of yogurt or other types of sour milk were proposed as solutions for the intestinal putrefaction that precipitated the aging process. He emphasized, in particular, the positive, neutralization effect of the so-called Bulgarian Bacillus from the Bulgarian yogurt upon intestinal microbiome, as proven by the health and longevity of the highlanders who include large amounts of soured milk in their diet. ${ }^{1-5}$

The actual discovery of the Lactobacillus bulgaricus is due to Stamen Grigoroff, a Bulgarian student who studied medical science in Geneva, Switzerland. Immediately after he identified the bacteria that cause the milk to curdle, his professor, Léon Massol wrote to Prof. Ilyja Mechnikoff at the Institut "Louis Pasteur", announcing the great scientific results. His discovery was presented in the paper entitled "Etude sur le lait fermenté comestible: le "Kissélo-mléko" de Bulgarie" and published in Revue médicale de la Suisse romande: organe officiel de la Société médicale de la Suisse romande, issue 10, dated 20.10.1905, Genève, Georg \& G., Libraries-Éditeurs. Librairie de L'Université. Then, it was validated by Metchnikoff, who invites the young scientist to Paris; his assistants, Luerssen and Kuhn, were those who in 1908 gave to this microorganism the designation of Lacto bacterium Bulgaricum the Bulgarian lactic bacteria.

In 1905 Radush Titkov, MD, defend a thesis in Toulouse concerning the healthy features of the yoghourt. Prof. Asen Zlatarov in 1933 said: "The yoghourt is an elixir of long-life". Acad Tasho Tashev and his school (1980-2001) research the role of the diary products in the treatment and prevention of the metabolic diseases.

\section{Materials and methods}

A total of 67 subjects with central type obesity (26 men and 41 women) were enrolled in the study. Baseline mean subject characteristics were: age-46.2 year old, body mass index (BMI)-35.4, fat mass (FM) $-39.4 \%$, visceral fat (VF)-14.1, waist circumference (W) $-109 \mathrm{~cm}$, hip circumference $(\mathrm{H})-120.2 \mathrm{~cm}$ and sagittal diameter (SD) $-27 \mathrm{~cm}$. All obese patients underwent a dietary regimen, included $290 \mathrm{~g}$ yoghurt fermented by Bifidus essensis for diner for a 6-month period. The product consisted of proteins $-4.3 \mathrm{~g}$, carbohydrates (lactose) $-3.9 \mathrm{~g}$, fat $-0.5 \mathrm{~g}$, and 7 kilocalories per $100 \mathrm{~g}$ yoghurt product. At the beginning and at the end of the study several anthropometric parameters (Height, Body weight, Body Mass Index, Fat Mass, Visceral Fat, Lean Body Mass (LBM), relation Lean body mass/Fat mass)have been measured by bioimpedance device (Tanita 420) and sagital diameter by caliper. ${ }^{6}$

\section{Results}

The study demonstrated decrease of BMI with $9.8 \%$ of fat mass with $9.6 \%$ of fat mass with $9.6 \%$ of visceral fat with $14 \%$ as well as a decrease of waist circumference- $11.9 \%$ hip circumference- $-5.8 \%$ and sagittal diameter-10.3\%. (Table 1 ) 
Table I $(n=67)$

\begin{tabular}{lcccccccccc}
\hline Parameters & BMI & $\begin{array}{l}\text { F } \\
(\%)\end{array}$ & $\begin{array}{l}\text { L B } \\
(\%)\end{array}$ & M & LBM/FM & VF & W(CM) & $\begin{array}{l}\text { H } \\
\text { (CM) }\end{array}$ & W/H & Sag.diameter \\
\hline Before treatment & 36.1 & 40.7 & 59.3 & 1.45 & 13 & 109.5 & 122.6 & 0.9 & 24.7 \\
After treatment & 32.2 & 36.2 & 63.8 & 1.8 & 11 & 98 & 114.6 & 0.87 & 22.8 \\
\hline
\end{tabular}

Moreover, in the end of the treatment we observed a trend in the improvement of the values of blood sugar, total cholesterol, triglycerides as well as of the systolic and diastolic blood pressure.

\section{Discussion}

Probiotics are substance that regulate the normal intestinal flora, influence metabolism and have an effect on various diseases. Our studies were performed on the effect of Lactobacillus bulgaricus and Bifidus Essensis carbohydrate and lipid metabolism in obesity. The results indicated that the probiotics improved the impaired glucose and lipid metabolism. The probiotics affected the concentration of free radicals in the blood. Taken together, the results give reason to assume role of the effect of probiotics on oxidative stress in the mechanism of influence on the metabolism. ${ }^{7-11}$

A number of studies on the properties of lactic acid bacteria strains suitable for the inclusion in a lot of functional starter cultures and fermented products were reported. L. bulgaricus strains with established in-vitro immunomodulating effect, L. helveticus-producer of bioactive peptides with ACE-inhibitory activity, L. Gasseri- with a strong adhesion to the epithelial cells of the gastrointestinal tract, and anti-cholesterol effect are selected. A variety of effective food additives and /or biologically active agents, probiotics are used in the management of obesity.

The foods containing physiologically active components (yoghurt) can improve considerably the health effect of every diet, e.g: normalizing of the body mass, increasing the resistance capacity of the immune system; decreasing the risk of some serious modern diseases such as cancer, ischemic heart desease, atherosclerosis, sugar diabetes, osteoporosis and others. The probiotics have been functional components of health foods for more than 100 years and their manufacturing has been continuously developed till the present day.

\section{Conclusion}

1. The regular consumption of yoghurt fermented by Bifidus essensis $(0.5 \%$ fat $)$ in the diet of obese patients leads to improvement of the studies anthropometric parameters as well as to significant decrease in the cardio-vascular risk.

2. Our study emphasizes the significance of yoghurt and other diary product in the prevention and management of metabolic and cardiovascular diseases.

\section{Acknowledgments}

None.

\section{Conflict of interest}

The author declares there is no conflict of interest.

\section{References}

1. Ahn HY, Kim M, Ahn YT, et al. The triglyceride-lowering effect of supplementation with dual probiotic strains, Lactobacillus curvatus HY7601 and Lactobacillus plantarum KY1032: Reduction of fasting plasma lysophosphatidylcholines in nondiabetic and hypertriglyceridemic subjects. Nutr Metab Cardiovasc Dis. 2015;25(8):724-733.

2. Beck AL, Heyman M, Chao C, et al. Full fat milk consumption protects against severe childhood obesity in Latinos. Prev Med Rep. 2017;23(8):15

3. Lamarche B, Givens DI, Soedamah-Muthu S, et al. Does Milk Consumption Contribute to Cardiometabolic Health and Overall Diet Quality? Can J Cardiol. 2016;32(8):1026-1032.

4. Bogdanov G. Probiotic as antioxidant in juvenile rats' fat-rich diet. Obesity facts. 2014;7(Supp1):66-67.

5. Ivey KL, Hodgson JM, Kerr DA, et al. The effect of yoghurt and its probiotics on blood pressure and serum lipid profile; a randomised controlled trial. Nutr Metab Cardiovasc Dis. 2015;25(1):46-51.

6. Handjieva-Darlenska T, Fr Roville-Sausse, Sv Handjiev. In: Nutrition et Sante. Sofia: Simel Press. p. 52-53.

7. Karimi G, Jamaluddin R, Mohtarrudin N, et al. Single-species versus dual-species probiotic supplementation as an emerging therapeutic strategy for obesity. Nutr Metab Cardiovasc Dis. 2017;27(10):910-918.

8. Mohammadi-Sartang M, Bellissimo N, Totosy de Zepetnek JO, et al. The effect of daily fortified yogurt consumption on weight loss in adults with metabolic syndrome: a 10-week randomized controlled trial. Nutr Metab Cardiovasc Dis. 2018;28(6):565-574.

9. Martinez-Gonzalez MA, Sayon-Orea C, Ruiz-Canela M, et al. Yogurt consumption, weight change and risk of overweight/obesity: the SUN cohort study. Nutr Metab Cardiovasc Dis. 2014;24(11):1189-1196.

10. Santiago S, Sayón-Orea C, Babio N, et al. Yogurt consumption and abdominal obesity reversion in the PREDIMED study. Nutr Metab Cardiovasc Dis. 2016;26(6):468-475.

11. Yumuk V, Tsigos C, Fried M, et al. European Guidelines for Obesity Management in Adults. Obes Facts. 2015;8(6):402-424. 